\title{
Comparison of two commercial formulations of Bacillus thuringiensis var. israelensis for the control of Anopheles aquasalis (Diptera: Culicidae) at three salt concentrations
}

\author{
Frances R Osborn+, Melfran J Herrera*, Cruz J Gómez*, Armando Salazar* \\ Instituto de Investigaciones en Biomedicina y Ciencias Aplicadas, Universidad de Oriente, Cumaná, Estado Sucre, Venezuela \\ *Laboratorio de Entomología Dr. J. V. Scorza, Gerencia de Saneamiento Ambiental y Malariología, Region XI, Carúpano, \\ Estado Sucre, Venezuela
}

Anopheles aquasalis larvae are salt water tolerant, preferring concentrations between 10 and 20 parts per thousand (ppt). The larvicidal efficacy of two formulations of Bacillus thuringiensis var. israelensis (Vectobac$12 A S^{\circledR}$ and Bactivec $\left.{ }^{\circledR}\right)$, was investigated against An. aquasalis at salinities of 0,10 , and 20 ppt. A probit analysis was used to calculate the lethal concentrations $\left(L C_{50}\right.$ and $\left.L C_{95}\right)$ for each product at each salinity. The $L C_{50}$ and $L C_{95}$ were higher for Bactivec ${ }^{\circledR}$ than Vectobac-12AS $S^{\mathrm{B}}$, and for Bactivec ${ }^{\circledR}$, the $L C_{50}$ and $L C_{95}$ increased with salinity. Vectobac-12AS $S^{\circledR}$ should thus be preferred to Bactivec ${ }^{\circledR}$ for An. aquasalis control, especially in saline breeding habitats.

Key words: Anopheles - sodium chloride - mosquito control

Malaria is one of the most important vector transmitted diseases in Venezuela with between 20,000 to 50,000 cases annually. The most important malaria states are Sucre, in the Northeastern part of the country, and Bolívar and Amazonas in the South. Malaria is endemic in Sucre state. During the years 2001 and 2002 Sucre produced the highest number, 40 and 56\% respectively, of cases in Venezuela. This has decreased significantly in more recent years, registering only 5266, 4746, and 4894 cases for 2003, 2004, and 2005 respectively, representing between 10 and $16 \%$ of all cases in Venezuela [Direccíon de Vigilancia Epidemiológica, Ministerio de Salud y Desarrollo Social, Venezuela (2001-2005)]. Nevertheless, the favorable environmental conditions for the vector; constant temperatures $\left(25-27^{\circ}\right)$ throughout the year, and the high number and large extent of the breeding grounds, coupled with the recent increase of the human population related to the exploitation of oil and gas in the region, has led to considerable concern regarding a possible resurgence of the disease.

In Sucre state, Anopheles aquasalis Curry is responsible for the overwhelming majority of malaria cases (Molina et al. 1997), which are almost exclusively caused by Plasmodium vivax. The immature phases of $A n$. aquasalis are found in diverse aquatic habitats, such as: lakes, canals, marshes, mangrove swamps or flooded fields, among others. The water in many of these breeding sites in Sucre state varies greatly in salinity; between

Financial support: Consejo de Investigación, Universidad de Oriente, Project CI-5-1901-0957/00, Fonacit, Project GI2000001541

${ }^{+}$Corresponding author: fosborn2001@yahoo.com

Received 8 June 2006

Accepted 29 November 2006
0.4 and 38.4 parts per thousand (ppt), equivalent to 1.14 and $110 \%$ seawater, respectively (Berti et al. 1993). Laboratory experiments have confirmed that this species is physiologically adapted to salinities of between 10 and 20 ppt (Gómez \& Osborn 2002).

Bacillus thuringiensis var. israelensis (Bti) is the most extensively used biological control agent in Venezuela. At present, the local health authorities responsible for malaria control in Sucre state employ an integrated management plan for control of the vector which includes biological control of larvae and chemical control of adults. As regards larval control, the health authorities use one or other of two commercial formulations of Bti: Vectobac-12AS ${ }^{\circledR}$ and Bactivec ${ }^{\circledR}$. Many factors can combine, however, to affect the performance of different formulations in the field (Becker et al. 1989, Castillo \& Scorza 1997). Since salt water is one of the most important factors for determining the distribution of An. aquasalis in Sucre state (Grillet et al 1998), we felt it necessary to evaluate the performance of these products in different salt concentrations under laboratory conditions, before their application in the field. This, in order to determine effective doses for each formulation with regard to the target species and salt concentration in the breeding grounds.

In this study, we tested the effect of three salt concentrations of the effectiveness of Vectobac $12 \mathrm{AS}^{\circledR}$ (1.6\% IA, 600 ITU/mg Valent Biosciences, US) and Bactivec $^{\circledR}$ (0.6\% IA, 600 ITU/mg Labiofam, Cuba) under laboratory conditions.

Larvae were obtained from field caught An. aquasalis females, collected following the methods of Delgado (1998) and Gómez and Osborn (2002) and identified using the keys of Cova-García and Sutil (1977).

The experiments were carried out in the Entomology Laboratory Dr. J. V. Scorza at the Gerencia de Saneamiento Ambiental y Malariología, Región XI, FUNDASALUD, Carúpano, Sucre state. Stock salt solutions of 0,10 and $20 \mathrm{ppt}$ sodium chloride (Instant 
Ocean ${ }^{\circledR}$, Aquarium Systems, US) were prepared in sodium chloride free potable water. An. aquasalis larvae were reared in $24 \times 16 \times 6 \mathrm{~cm}$ plastic trays containing $200 \mathrm{ml}$ of each stock salt solution at a temperature of $27 \pm 0.5^{\circ} \mathrm{C}, \%$ humidity $80 \pm 5$, and photoperiod $12: 12$, using the methods of Delgado (1998) and Gómez and Osborn (2002).

Ten late third or early fourth instars were placed in round plastic containers, with a surface area of $83 \mathrm{~cm}^{2}$ and depth $5 \mathrm{~cm}$, holding $100 \mathrm{ml}$ of the salt solution to be tested. Vectobac- $12 \mathrm{AS}^{\circledR}$ at $1,0.5,0.3,0.1$, and $0.05 \mathrm{ppm}$ was tested at each salt concentration $(\mathrm{ppm}=$ parts per million of active ingredient), Bactivec ${ }^{\circledR}$ was tested at 10 , $5,1,0.5$, and $0.1 \mathrm{ppm}$ in fresh water $(0 \mathrm{ppt})$, whereas for 10 and $20 \mathrm{ppt}, 10,5,3,2$, and $1 \mathrm{ppm}$, rates of Bactivec ${ }^{\circledR}$ were used. The lower rates of Bactivec ${ }^{\circledR}$ were raised in 10 and 20 ppt due to the low mortality obtained at product concentrations of 0.5 and $0.1 \mathrm{ppm}$. Six replicas were done for each product and salt concentration plus six untreated controls with 10 late third or early fourth instars in each control for each salt concentration.

Larval mortality was recorded $24 \mathrm{~h}$ after treatment and corrected using Abbott's formula (Abbott 1925) when the mortality of the controls exceeded $5 \%$ :

$\%$ corrected mortality $=(\mathrm{X}-\mathrm{Y} / \mathrm{X}) \times 100$

where: $\mathrm{X}=\%$ of live larvae in the control; $\mathrm{Y}=\%$ of live larvae in the treatment.

All experiments were repeated on three different occasions in order to correct for differences due to manipulation of the larvae and intrinsic population differences (Mulla 1990). The percentages of mortality obtained were analyzed with Probit analyses (Finney 1971), using the Probit Analysis option in the SPSS 10.0 package for Windows: PSS Inc.

Once the lethal concentrations had been calculated, the $\mathrm{CL}_{95} / \mathrm{CL}_{50}$ relationship was calculated in order to determine the number of times it is necessary to increase
$\mathrm{LC}_{50}$ in order to obtain the $\mathrm{LC}_{95}$, which can be used to indicate the efficiency of the formulation against a particular species (Lacey \& Singer 1982).

The results from the Probit analysis indicate that the $\mathrm{LC}_{50}$ and $\mathrm{LC}_{95}$ values for Vectobac $12 \mathrm{AS}^{\circledR}$ were approximately 5-10 times less than the $\mathrm{LC}_{50}$ and $\mathrm{LC}_{95}$ values for Bactivec ${ }^{\circledR}$ in all the salt concentrations studied (Table).

Salinity adversely affected Bactivec ${ }^{\circledR}$ efficacy, as shown by the increase in $\mathrm{LC}_{50}$ and $\mathrm{LC}_{95}$ values with increased salinity. Vectobac ${ }^{\circledR}$, however, remained unaffected by the tested salinities. When the $\mathrm{LC}_{50}$ and $\mathrm{LC}_{95}$ values for Bactivec ${ }^{\circledR}$ were plotted against salinity, significant linear relations were found for salinities between 0 and $20 \mathrm{ppt}$; for $\mathrm{LC}_{50} \mathrm{y}=0.068 \mathrm{x}+0.875\left(\mathrm{R}^{2}=1.0 ; \mathrm{p}=\right.$ $0.004)$, and for $\mathrm{LC}_{95} \mathrm{y}=0.23 \mathrm{x}+5.04\left(\mathrm{R}^{2}=0.999 ; \mathrm{p}=\right.$ $0.019)$ (SPSS 10.0 for windows).

The efficiencies of both formulations were largely unaffected by salinity, however, this seemed to be slightly improved with increasing salt concentrations for Bactivec $^{\circledR}$.

Gómez (2001 unpublished observations), evaluated Vectobac- $G^{\circledR}$ under similar laboratory conditions against An. aquasalis larvae from Sucre state at $0 \mathrm{ppt}$ salinity, and found $\mathrm{LC}_{50}$ and $\mathrm{LC}_{95}$ values of 0.95 and $8.28 \mathrm{ppm}$ respectively, much higher than the $\mathrm{LC}_{50}$ and $\mathrm{LC}_{95}$ found in this experiment ( 0.2 and $0.67 \mathrm{ppm}$ respectively) and an efficiency of 8.72 ; less than half that obtained in this experiment for 0 ppt salinity (3.35), indicating that Vectobac-12AS ${ }^{\circledR}$ is more efficient than Vectobac- $G^{\circledR}$ for controlling larval An. aquasalis populations in Sucre state.

Different authors have evaluated the efficiency of Vectobac-12AS ${ }^{\circledR}$ and Bactivec ${ }^{\circledR}$ against An. aquasalis larvae under laboratory conditions with varying results. Delgado (1996 unpublished observations) and Moreno et al. (2003), tested Vectobac-12AS ${ }^{\circledR}$ and Bactivec ${ }^{\circledR}$, respectively, in fresh water against An. aquasalis larvae

TABLE I

Probit analysis for Vectobac-12AS ${ }^{\circledR}$ and Bactivec ${ }^{\circledR}$ in three salt concentrations against Anopheles aquasalis larvae under laboratory conditions

\begin{tabular}{|c|c|c|c|}
\hline \multicolumn{4}{|c|}{ Vectobac-12AS ${ }^{\circledR}$} \\
\hline & & Salinity (ppt) & \\
\hline Parameters & 0 & 10 & 20 \\
\hline Slope \pm SD & $3.18 \pm 0,16$ & $2.23 \pm 0,13$ & $2.5 \pm 0,1$ \\
\hline $\mathrm{LC}_{50}(\mathrm{ppm})$ Confidence limits $95 \%$ & $0.20 .13-0.3$ & $0.15 .09-0.21$ & $0.19 .13-0.28$ \\
\hline $\mathrm{LC}_{95}(\mathrm{ppm})$ Confidence limits $95 \%$ & $0.67 .42-1.76$ & $0.80 .47-2.26$ & $0.85 .53-1.97$ \\
\hline Efficiency $\left(\mathrm{LC}_{95} / \mathrm{LC}_{50}\right)$ & 3.35 & 5.33 & 4.47 \\
\hline \multicolumn{4}{|c|}{ Bactivec $^{\circledR}$} \\
\hline & \multicolumn{3}{|c|}{ Salinity (ppt) } \\
\hline Parameters & 0 & 10 & 20 \\
\hline Slope \pm SD & $2.19 \pm 0.12$ & $2.39 \pm 0.17$ & $2.52 \pm 0.16$ \\
\hline $\mathrm{LC}_{50}(\mathrm{ppm})$ Confidence limits $95 \%$ & $0.89 .66-1.2$ & $1.53 .36-1.71$ & 2.24.04-2.44 \\
\hline $\mathrm{LC}_{95}^{50}(\mathrm{ppm})$ Confidence limits $95 \%$ & $5.05 .25-10.13$ & 7.52.35-9.35 & $10.05 .49-12.41$ \\
\hline Efficiency $\left(\mathrm{LC}_{95} / \mathrm{LC}_{50}\right)$ & 5.67 & 4.92 & 4.49 \\
\hline
\end{tabular}

ppt: parts per thousand; ppm: parts per million. 
bred from adults collected from the same site at Lake Valencia, Carabobo state. In both studies, far lower $\mathrm{LC}_{50}$ and $\mathrm{LC}_{95}$ values were reported than those in the current study: 0.013 and $0.10 \mathrm{ppm}$ for Vectobac-AS $12^{\circledR}$ by Delgado (1996 unpublished observations) and 0.111 and 0.263 ppm for Bactivec ${ }^{\circledR}$ by Moreno et al. (2003). Although this could mean that An. aquasalis larvae from Lake Valencia are more susceptible to these products than An. aquasalis from Sucre state, more studies are needed to confirm this.

Other anopheline species show similar levels of susceptibility to Vectobac-12AS ${ }^{\circledR}$. For example, the $\mathrm{LC}_{50}$ dose for An. stephensi from Pondicherrry, India, was 0.19 ppm (Dominic Amalraj et al. 2000). Other mosquito genera, however, may be far more susceptible; in a study undertaken by Nayar et al. (1999) against early fourth instar Culex nigripalpus, Vectobac-12AS ${ }^{\circledR}$ had a $\mathrm{LC}_{50}$ of $0.088 \mathrm{ppm}$, although Dominic Amalraj et al. (2000) reported a $\mathrm{LC}_{50}$ for Aedes taeniorhynchus of $0.164 \mathrm{ppm}$, comparable to that of An. stephensi.

On the other hand, in an experiment undertaken by Delgado et al. (2001), in Santo Domingo, Dominican Republic, An. albimanus larvae were more resistant to Bactivec $^{\circledR}$ than the An. aquasalis larvae used in the current experiment. These authors could not determine the diagnostic concentration (DC), for Bactivec ${ }^{\circledR}$; (DC: minimum concentration of product that produces $100 \%$ mortality) after 24 and $48 \mathrm{~h}$ of exposition against $\mathrm{An}$. albimanus, due to the low mortality of the larvae, even at the highest concentration used of $12 \mathrm{ppm}$, whereas 5.05 ppm killed $95 \%$ of An. aquasalis larvae in this study.

The potency of products may also depend on differences in sample processing and pretest rearing of the mosquito species between laboratories (Skovmand et al. 1998). It is thus difficult to make comparisons between studies, even those dealing with the same product and species.

Very few studies have explored the effect of salinity on the performance of bacteria-based larvicides, even though several mosquito pests are saltwater tolerant, such as. Cx. sitiens, Ae. taeniorhynchus, An. faruti, An. aquasalis, etc. Increasing salinity levels from fresh water to $50 \%$ seawater (about $17.5 \mathrm{ppt}$ ), caused a decline in the efficiency of Vectobac 12AS ${ }^{\circledR}$ and Vectobac $\mathrm{TP}^{\circledR}$ against Ae. taeniorhynchus larvae in Florida, US (Nayar et al. 1999). Nevertheless, salinity concentrations of 10 , 20 , and $30 \%$ seawater $(3.5,7$, and $10.5 \mathrm{ppt})$ did not affect the spore dormancy of $B$. sphaericus 2362 (Yousten et al. 1992). Nayar et al. (1999), suggest that the decline in the effectiveness of the larvicides is due to a decrease in the susceptibility of the larvae in increasing salt concentrations. Nevertheless, in this study only Bactivec ${ }^{\circledR}$ was affected negatively by salinity, suggesting that there may be a direct effect of salt on the bacteria or other ingredients in the formulation.

The results from the studies mentioned demonstrate that there is a high variability in the dose-mortality response between products, mosquito species and even for populations within species, thus suggesting the need for constant monitoring in the regions where they are used. From the results of our study, however, we recommend the use of Vectobac-12AS ${ }^{\circledR}$ rather than Bactivec ${ }^{\circledR}$, for the control of An. aquasalis in Sucre state, especially in saline breeding habitats.

\section{ACKNOWLEGMENTS}

To the personal of the Gerencia de Salud Ambiental, Region XI, for help with the collection of adult mosquitoes.

\section{REFERENCES}

Abbott W 1925. A method of computing the effectiveness of an insecticide. J Econ Entomol 18: 265-267.

Becker N, Zgomba M, Ludwig M, Pectric D, Rettich F 1989. Factors influencing the activity of Bacillus thuringiensis var. israelensis treatments. J Am Mosq Control Assoc 8: 285289.

Berti J, Zimmerman R, Amarista J 1993. Spatial and temporal distribution of Anopheline larvae in two malarious areas in Sucre state, Venezuela. Mem Inst Oswaldo Cruz 88: 353362.

Castillo C, Scorza J 1997. La luz solar como factor limitante de la actividad larvicida de una formulación asporógena de Bacillus thuringiensis $\left(\right.$ Teknar $\left.^{\circledR}\right)$ in vitro. Bol Dir Malar San Amb 37: 14-18.

Cova-García P, Sutil E 1977. Claves Gráficas para la Clasificación de Anofelinos de Venezuela, Escuela de Malariología y Saneamiento Ambiental, Maracay, Venezuela, $92 \mathrm{pp}$.

Delgado N 1996. Implicaciones ecofisiológicas de la introducción de Bacillus thuringiensis var. israelensis como controlador biológico de Anopheles aquasalis (Diptera: Culicidae). [Unpublished dissertation]. Universidad Central de Venezuela, Maracay, $259 \mathrm{pp}$.

Delgado N 1998. Parámetros demográficos de las fases inmaduras de Anopheles aquasalis Curry 1932 (Diptera: Culicidae) en condiciones de laboratorio. Bol Entomol Venezolana 13: 27-43.

Delgado N, Solís A, Guzmán G, Ventura G, De Los Santos J, Montero D, Gonzálvez G 2001. Determinación de las concentraciones diagnósticas de cuatro formulaciones comerciales de Bacillus thuringiensis var. israelensis y $B$. sphaericus, sobre Aedes aegypti, Culex quinquefasciatus y Anopheles albimanus (Diptera: Culicidae) en Santo Domingo, República Dominicana. XVII Congreso Venezolano de Entomología, Maturín, Venezuela, p. 91 (Abstract).

Direccion de Vigilancia Epidemiologica, Ministerio de Salud y Desarrollo Social, Venezuela (2001-2005). Epidemiological Bulletin, years 51-55 (downloadable at www.msds.gov.ve).

Dominic Amalraj D, Sahu S, Jambulingam P, Boopathi Doss P, Kalyanasundaram M, Das P 2000. Efficacy of aqueous suspensión and granular formulations of Bacillus thuringiensis (Vectobac) against mosquito vectors. Acta Trop 75: 243-246.

Finney D 1971. Probit Analysis, The syndics of the Cambridge University Press, Cambridge, 400 pp.

Gómez C 2001. Efecto de diferentes concentraciones de salinidad sobre una formulación comercial de Bacillus thuringiensis israelensis Berliner, controlador biológico de Anopheles aquasalis Curry, (Diptera: Culicidae) en el laboratorio. [Unpublished dissertation]. Universidad de Oriente, Cumaná, $47 \mathrm{pp}$. 
Gómez C, Osborn F 2002. Efectos de differentes concentraciones salinas sobre el desarrollo de larvas y pupas de Anopheles aquasalis Curry, 1932 (Diptera: Culicidae) en condiciones de laboratorio. Entomotropica 17: 121-127.

Grillet M, Montañez H, Berti J 1998. Estudios biosistemáticos y ecológicos sobre Anopheles aquasalis en el estado Sucre: II - Ecología de sus criaderos. Bol Dir Malariol San Amb 38: $38-46$.

Lacey L, Singer S 1982. Larvicidal activity of new isolates of Bacillus sphaericus and Bacillus thuringiensis var. israelensis (H-14) againts anopheline and culicine mosquitoes. Mosq News 42: 537-543.

Molina D, Saume F, Bisset J, Hidalgo O, Castillo M, Amaya W, González J, Salas O, Barazarte H 1997. Establecimiento de la línea de susceptibilidad de la fase adulta de Anopheles spp. a insecticidas químicos. Bol Dir Malar San Amb 37: 55-69.

Moreno J, Delgado N, González J 2003. Evaluación de la eficacia de una formulación comercial de Bacillus thuringiensis israelensis en condiciones de laboratorio sobre Anopheles albimanus Wied. y Anopheles aquasalis Curry del lago de Valencia. XVII Congreso Venezolano de Entomología, Maracay, Venezuela, p. 51 (Abstract).

Mulla M 1990. Activity, field efficacy and use of Bacillus thuringiensis israelensis against mosquitoes. In $\mathrm{H}$ de Barjac, D Sutherlands (eds), Bacterial Control of Mosquitoes \& Black Flies, Rutgers Univ Press, New Brunswick, NJ, p. 134-160.

Nayar J, Knight J, Ali A, Carlson D, O’Bryan P 1999. Laboratory evaluation of biotic and abiotic factors that may influence larvicidal activity of Bacillus thuringiensis serovar israelensis against two Florida mosquito species. J Mosq Cont Ass 15: 32-42.

Skovmund O, Thiery I, Benzon G, Sinègre G, Monteny N, Becker N 1998. Potency of products based on Bacillus thuringiensis var. israelensis: interlaboratory variations. J Mosq Cont Ass 14: 298-304.

Yousten A, Genthner F, Benfield E 1992. Fate of Bacillus sphaericus and Bacillus thuringiensis serovar israelensis in the aquatic environment. J Mosq Cont Ass 8: 143-148. 